\title{
IMPLEMENTASI CONTEXTUAL TEACHING AND LEARNING (CTL) BERBASIS MULTIMEDIA INTERAKTIF DALAM PEMBELAJARAN IMAN KEPADA HARI AKHIR SEBAGAI UPAYA PENINGKATAN KEAKTIFAN DAN HASIL BELAJAR PESERTA DIDIK KELAS IX A SMP NEGERI 2 TENGARAN
}

\author{
AMIN NURBAEDI \\ GPAI SMP Negeri 2 Tengaran Kab. Semarang Prov. Jawa Tengah
}

\begin{abstract}
The aim of this research is to determine the implementation Contextual Teaching and Learning (CTL) based on interactive multimedia, whether it can enhance the activity and learning outcomes in matter of faith in the final days. This research is a classroom action research which is carried out in three cycles. Each cycle consists of four stages: planning, implementation, observation, and reflection. Data were collected using an achievement test, observation guidelines, field notes, and the records of learners. Data have been presented as percentages and analyzed using inductive, deductive, and comparative ways. Improvement in learning outcomes also occurred as evidenced by comparing the value at pre-action, the first cycle, second cycle and third cycle. In pre-action activities, the maximum score is 100; and also for the first, second, and third cycle. The achievement of a minimum value on pre-action activity continued to increase by 50 and 10 points to 60 in the first cycle, 70 in the second cycle, and 80 in the third cycle. The average value also increased significantly. On learning pre-action, the average value of only 84 . In the second cycle increased to 90 , on the second cycle and the third cycle increased to 92 . The percentage of completeness increased from 77.42 on learning pre-action, turned into 87.10 in the second cycle, 96.77 in the second cycle, and 100 percent in the third cycle.
\end{abstract}

Keywords: Contextual Teaching and Learning (CTL), interactive multimedia, active, learning outcomes.

\begin{abstract}
Abstrak
Learning (CTL) berbasis multimedia interaktif dapat meningkatkan keaktifan dan hasil belajar Peserta didik dalam materi iman kepada hari akhir. Penelitian ini adalah penelitian tindakan kelas yang dilaksanakan dalam tiga siklus. Masing-masing siklus terdiri dari empat tahap yaitu perencanaan, pelaksanaan, observasi, dan refleksi. Data dikumpulkan dengan menggunakan test hasil belajar, pedoman observasi, catatan lapangan, dan catatan peserta didik. Data disajikan dalam bentuk persentase dan dianalisis dengan analisis induktif, deduktif, dan komparatif. Peningkatan dalam hasil belajar juga terjadi yang dibuktikan dengan membandingkan nilai pada pratindakan, siklus I, siklus II, dan siklus III. Pada kegiatan pratindakan, nilai maksimal sebesar 100. Begitu juga pada siklus I, II,
\end{abstract}


dan III. Pencapaian nilai minimal pada kegiatan pratindakan sebesar 50 dan terus meningkat 10 point menjadi 60 pada siklus I, 70 pada siklus II, dan 80 pada siklus III. Nilai rata-rata juga mengalami kenaikan yang cukup signifikan. Pada pembelajaran pratindakan, nilai rata-rata hanya sebesar 84. Pada siklus kedua meningkat menjadi 90, pada siklus II dan siklus III meningkat menjadi 92. Begitu juga dengan persentase ketuntasan meningkat dari 77.42 pada pembelajaran pratindakan, berubah menjadi 87.10 pada siklus II, 96.77 pada siklus II, dan 100 persen pada siklus III.

Kata Kunci: Contextual teaching and learning (CTL), multimedia interaktif, keaktivan, hasil belajar

\section{PENDAHULUAN}

\section{Latar Belakang Masalah}

Sudah satu minggu lebih Peserta didik kembali belajar, namun dampak libur panjang akhir tahun masih terasa. Peserta didik kurang bersemangat dalam belajar. Apalagi, kegiatan pembelajaran pada minggu pertama masuk sekolah masih belum efektif. Masa Orientasi Siswa Baru (MOS) 2015 dan kegiatan menjelang peringatan HUTRI ke 69 membuat kegiatan pembelajaran terganggu. Iqbal Adi Ash-Shiddiqy dan Ahmad Juang Setyawan terlambat 3 menit untuk mengikuti pembelajaran Pendidikan Agama Islam dan Budi Pekerti . Padahal sebelumnya pendidik telah memberitahukan bahwa pembelajaran pada tanggal 27 Juli 2015 merupakan pembelajaran pratindakan dalam penelitian tindakan kelas. Keduanya tidak mendengarkan penjelasan tentang KI KD dan tujuan pembelajaran pada hari itu.

Walaupun demikian keduanya juga kurang memperhatikan ketika pendidik memberikan pengantar materi pembelajaran. Bahkan Juang malah mengganggu M. Ryan Ghadafi yang duduk di kursi pada deret samping kanannya. Mereka mulai tampak serius ketika diadakan pretest dan mengetahui kalau hasilnya akan dinilia. "Apakah ini dinilai, Pak?" tanya Juang sebelum pretest dilaksanakan. Namun hal itu tidak berlangsung lama, ketika pendidik memberikan pertanyaan untuk memancing rasa ingin tahunya, mereka kurang serius menjawabnya. Begitu juga ketika video tentang hari kiamat ditampilkan, keduanya malah asyik berbicara sendiri. Selain itu, Wahyu Aji Safitri yang duduk di kursi yang terletak pada deretan paling depan juga tampak kurang bersemangat. Berulang kali dia menghela nafas panjang dan menundukkan kepala.

Saat belajar kelompok pun mereka tidak mencari jawaban dengan membaca buku ajar dan LKS yang ada. Buku catatan mereka juga kosong dan saat mereka diminta 
untuk menjawab pertanyaan juga tidak bisa menjawab dengan baik atau bahkan hanya diam. Akibat dari ketidakaktivan Peserta didik dalam pembelajaran menyebabkan hasil posttest merekapun tidak menunjukkan penguasaan yang maksimal terhadap materi pembelajaran. M. Iqbal yang mendapatkan nilai 70 pada saat pretest dan posttes. Begitu juga dengan Ahmad Juang, nilainya menurun dari 70 menjadi 50. Sedangkan nilai Ibn Akhmad juga menurun dari 90 menjadi 80. Walaupun prosentase ketuntasan antar pretest dan posttest sama, yakni sebesar $70.83 \%$ tetapi nilai rata-rata hasil belajar kelas IX A menurun dari 84 menjadi 83 dan nilai terendah juga mengalami penurunan dari 60 menjadi 50. Secara umum, hasil belajar siswa pada kondisi pra tindakan dapat dilihat dalam tabel berikut:

Tabel 1. Perbandingan Nilai Pretest dan Posttest

\begin{tabular}{|c|l|c|c|c|}
\hline \hline No & \multicolumn{1}{|c|}{ Uraian } & Pretest & Postest & Ket \\
\hline \hline 1. & Nilai Tertinggi & 90 & 100 & Meningkat \\
\hline 2. & Nilai Terendah & 60 & 50 & Menurun \\
\hline 3. & Rata-rata & 81 & 84 & Meningkat \\
\hline 4. & Persentase Ketuntasan & 52.38 & 70.83 & Meningkat \\
\hline
\end{tabular}

Oleh karena itulah penulis mengadakan penelitian tindakan kelas dengan judul "Implementasi Contextual Teaching and Learning (CTL) Berbasis Multimedia Interaktif dalam Pembelajaran Iman kepada Hari Akhir sebagai Upaya Peningkatan Keaktifan dan Hasil Belajar Peserta didik Kelas IX A SMP Negeri 2 Tengaran Kab. Semarang"

\section{Perumusan Masalah}

a. Apakah implementasi Contextual Teaching and Learning (CTL) berbasis multimedia interaktif dapat meningkatkan keaktifan Peserta didik IX A SMP Negeri 2 Tengaran Kab. Semarang dalam pembelajaran Iman kepada Hari Akhir?

b. Apakah implementasi Contextual Teaching and Learning (CTL) berbasis multimedia interaktif dapat meningkatkan hasil belajar Peserta didik kelas IX SMP Negeri 2 Tengaran Kab. Semarang dalam pembelajaran Iman kepada Hari Akhir?

\section{Pembahasan}

a. Peningkatan Keaktifan Peserta didik

Untuk mengetahui adanya peningkatan keaktifan Peserta didik dalam belajar digunakan beberapa instrument penelitian. Peningkatan keaktifan Peserta didik dalam kegiatan pembelajaran dilihat dalam bentuk kegiatan yang dilakukan Peserta 
didik dalam pembelajaran. Adapun kegiatan Peserta didik dalam pembelajaran antara lain:

1) masuk kelas tepat waktu;

2) aktif dalam kegiatan tanya jawab;

3) aktif membaca kompetensi pembelajaran;

4) mempelajari materi pembelajaran;

5) menonton video motivasi;

6) aktif dalam belajar kelompok;

7) mencatat materi pembelajaran;

8) membaca dan memahami kesimpulan;

9) melakukan refleksi pembelajaran; dan

10) mengerjakan soal latihan.

Data tersebut diperoleh dari beberapa instrument penelitian yang berupa observasi kepada peserta didik, catatan kolabor, dan catatan peserta didik. Keaktifan Peserta didik diketahui melalui observasi tertruktur yang dilakukan oleh guru kolabor. Adapun hasil observasi tersebut adalah sebagai berikut:

Tabel Peningkatan Keaktifan Peserta didik dalam Proses Pembelajaran

\begin{tabular}{|l|l|c|c|c|}
\hline \multirow{2}{*}{ No } & \multicolumn{2}{|c|}{ Kegiatan } & \multicolumn{3}{c|}{ Persentase Keaktifan Peserta Didik } \\
\cline { 3 - 5 } & & Siklus I & Siklus II & Siklus III \\
\hline 1. & Masuk kelas tepat waktu & 90.3 & 100 & 100 \\
\hline 2. & Aktif dalam kegiatan tanya jawab & 12.9 & 32.3 & 45.2 \\
\hline 3. & Aktif membaca kompetensi pembelajaran & 100 & 100 & 100 \\
\hline 4. & Mempelajari materi pembelajaran & 100 & 100 & 100 \\
\hline 5. & Menonton video motivasi & 100 & 100 & 100 \\
\hline 6. & Aktif dalam belajar kelompok & 32.3 & 83.9 & 96.8 \\
\hline 7. & Mencatat materi pembelajaran & 64.5 & 80.6 & 100 \\
\hline 8. & Membaca dan memahami kesimpulan & 74.2 & 93.5 & 100 \\
\hline 9. & Melakukan refleksi pembelajaran & 100 & 100 & 100 \\
\hline 10. & Mengerjakan soal latihan & 100 & 100 & 100 \\
\hline
\end{tabular}

Berdasarkan tabel di atas dapat diketahui bahwa pada dasarnya pendekatan CTL berbasis multimedia pembelajaran interaktif membuat Peserta didik aktif dalam belajar. Terutama dalam mempelajari materi atau kegiatan yang ada pada media tersebut. Hal itu tampak pada kesenjangan antara kegiatan pembelajaran yang mengharuskan Peserta didik untuk belajar dengan media dan tidak. Semua Peserta didik menggunakan media tersebut dengan baik, sebesar $100 \%$. Persentase keaktifan 
Peserta didik cukup rendah dalam kegiatan yang tidak menuntut penggunaan media, seperti keaktifan dalam tanya jawab, keaktifan dalam belajar kelompok, mempresentasikan hasil belajar kelompok. Namun pada siklus III terjadi peningkatan yang cukup berarti, walaupun belum mencapai $100 \%$. Sedangkan dalam mencatat materi pembelajaran, keaktifan Peserta didik cukup baik, walaupun belum $100 \%$ pada siklus I dan II. Semua Peserta didik baru mencatat materi pembelajaran pada siklus III. Untuk lebih jelasnya, peningkatan keaktifan Peserta didik dalam proses pembelajaran dapat dilihat dalam grafik berikut:

Grafik Peningkatan Keaktifan Peserta didik dalam Pembelajaran

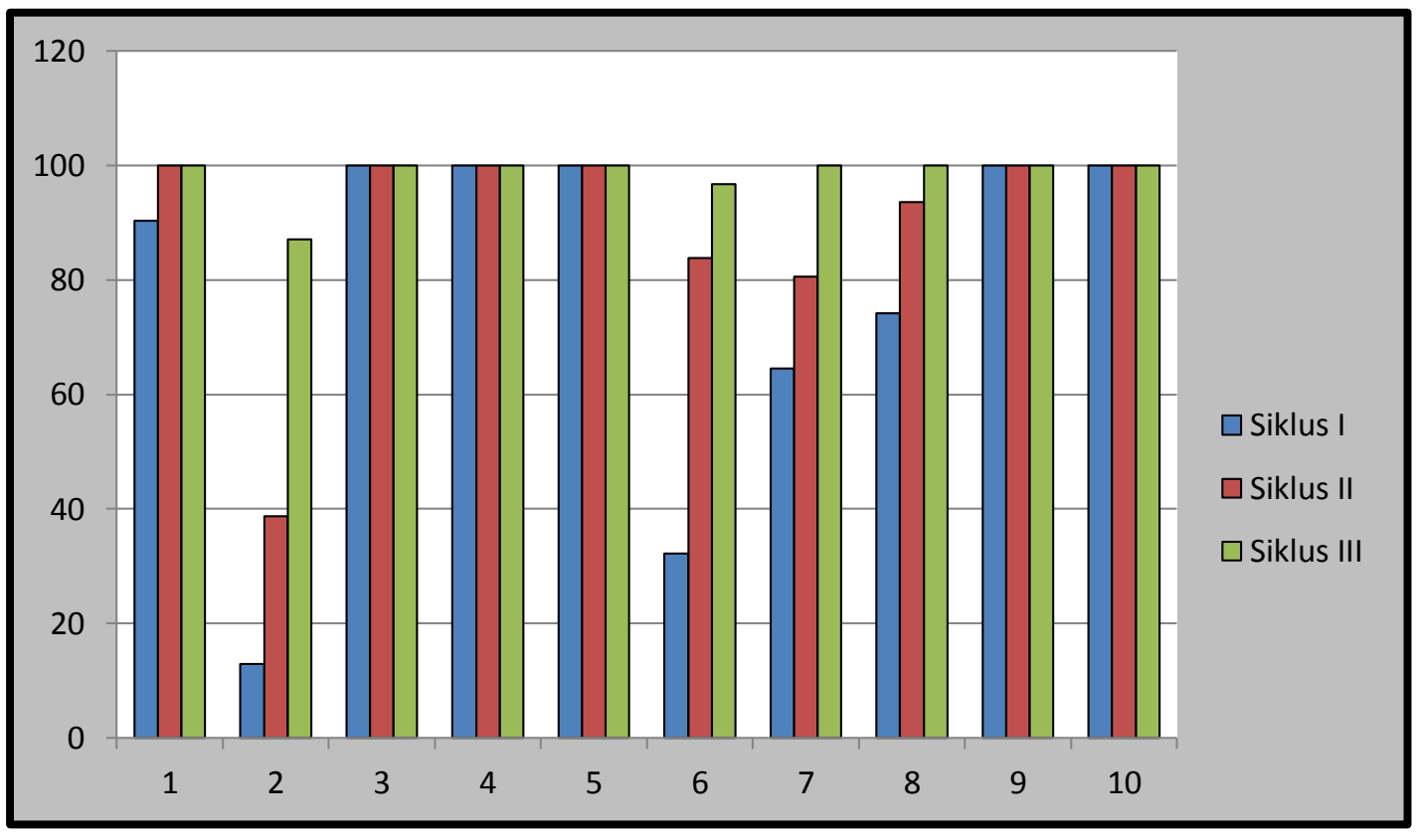

Adapun deskripsi peningkatan keaktifan belajar mulai dari pratindakan, siklus I, siklus II, dan siklus III, adalah sebagai berikut:

Tabel Peningkatan Keaktifan Peserta didik dalam Pembelajaran

\begin{tabular}{|c|c|c|c|c|c|}
\hline No & Pratindakan & Siklus I & Siklus II & Siklus III & Refleksi \\
\hline \multirow[t]{9}{*}{1} & Peserta didik & Peserta didik & Peserta didik & Semua & Peserta didik \\
\hline & yang pasif & yang pasif & yang & Peserta didik & pasif \\
\hline & mulai & sedikit: tidak & sedikit: tidak & aktif dalam & berkurang dari \\
\hline & berkurang & ada yang & ada yang & pembelajaran & sedikit \\
\hline & atau agak & berbicara, & berbicara, & & menjadi tidak \\
\hline & banyak. & bermain, dan & bermain, dan & & ada. \\
\hline & Mereka & tidak & tidak & & \\
\hline & masih & mengantuk & mengantuk & & \\
\hline & berbicara & & & & \\
\hline
\end{tabular}




\begin{tabular}{|l|l|l|l|l|l|}
\hline $\begin{array}{l}\text { sendiri, } \\
\text { bermain, } \\
\text { tertawa, } \\
\text { tetapi tidak } \\
\text { mengantuk }\end{array}$ & & & & \\
\hline 2 & $\begin{array}{l}\text { Sebagian } \\
\text { Peserta didik } \\
\text { mulai } \\
\text { bertanya } \\
\text { materi } \\
\text { pembelajaran } \\
\text { dan berani } \\
\text { menjawab } \\
\text { pertanyaan. }\end{array}$ & $\begin{array}{l}\text { Sedikit sekali } \\
\text { pasif yang } \\
\text { malas bertanya }\end{array}$ & $\begin{array}{l}\text { Sedikit Peserta } \\
\text { didik yang } \\
\text { pasif dan } \\
\text { malas bertanya }\end{array}$ & $\begin{array}{l}\text { Hampir } \\
\text { semua } \\
\text { Peserta didik } \\
\text { aktif dan } \\
\text { senang } \\
\text { bertanya }\end{array}$ & $\begin{array}{l}\text { Peserta didik } \\
\text { yang malas } \\
\text { bertanya } \\
\text { berkurang dari } \\
\text { sedikit } \\
\text { menjadi } \\
\text { hampir semua }\end{array}$ \\
\hline 3 & $\begin{array}{l}\text { Keaktifan } \\
\text { belajar } \\
\text { Peserta didik } \\
\text { agak tinggi }\end{array}$ & $\begin{array}{l}\text { Keaktifan } \\
\text { belajar Peserta } \\
\text { didik tinggi }\end{array}$ & $\begin{array}{l}\text { Keaktifan } \\
\text { belajar Peserta } \\
\text { didik tinggi }\end{array}$ & $\begin{array}{l}\text { Keaktifan } \\
\text { belajar } \\
\text { Peserta didik } \\
\text { sangat tinggi }\end{array}$ & $\begin{array}{l}\text { Keaktifan } \\
\text { belajar Peserta } \\
\text { didik } \\
\text { meningkat } \\
\text { dari tinggi } \\
\text { menjadi sangat } \\
\text { tinggi }\end{array}$ \\
\hline
\end{tabular}

b. Peningkatan Hasil Belajar

Pembelajaran dengan pendekatan CTL berbasis multimedia pembelajaran interaktif berdampak positif terhadap peningkatan hasil belajar Peserta didik pada materi iman kepada hari akhir. Walaupun Jumlah Maksimal masing-masing siklus sebesar 100. Tetapi jumlah pencapaian nilai tersebut terus bertambah setiap siklusnya. Begitu juga pada nilai rata-rata kelas dan persentase ketuntasan yang mengalami peningkatan signifikan. Peningkatan tersebut tidak lepas dari proses pembelajaran yang dilakukan oleh pendidik. Untuk lebih jelasnya, peningkatan hasil belajar Peserta didik mulai dari pembelajaran pratindakan, siklus I, siklus II, dan siklus III dijelaskan dalam tabel berikut:

Tabel 35: Perbandingan Hasil Belajar Peserta Didik 


\begin{tabular}{|l|l|c|c|c|c|}
\hline No & Uraian & Pratindakan & Siklus I & Siklus II & Siklus III \\
\hline 1. & Jumlah Maksimal & 100 & 100 & 100 & 100 \\
\hline 2. & Nilai Minimal & 50 & 60 & 70 & 80 \\
\hline 3. & Rata-rata & 84 & 90 & 92 & 92 \\
\hline 4. & Persentase Ketuntasa & 77.42 & 87.10 & 96.77 & 100 \\
\hline
\end{tabular}

Pada kegiatan pratindakan, Jumlah Maksimal sebesar 100. Begitu juga pada siklus I, II, dan III. Pencapaian nilai minimal pada kegiatan pratindakan sebesar 50 dan terus meningkat 10 point menjadi 60 pada siklus I, 70 pada siklus II, dan 80 pada siklus III. Nilai rata-rata juga mengalami kenaikan yang cukup signifikan. Pada pembelajaran pratindakan, nilai rata-rata hanya sebesar 84. Pada siklus kedua meningkat menjadi 90, pada siklus II dan siklus III meningkat menjadi 92. Begitu juga dengan persentase ketuntasan meningkat dari 77.42 pada pembelajaran pratindakan, berubah menjadi 87.10 pada siklus II, 96.77 pada siklus II, dan 100 persen pada siklus III.

Berdasarkan tabel dan penjelasan di atas dapat disimpulkan bahwa pembelajaran dengan pendekatan CTL berbasis multimedia pembelajaran interaktif telah meningkatakn hasil belajar Peserta didik pada materi iman kepada hari akhir. Peningkatan nilai tersebut tidak lepas dari keaktifan Peserta didik selama belajar. Mereka belajar mandiri dengan mengakses materi pembelajaran melalui tombol navigasi yang terdapat pada media tersebut. Proses tersebut menuntut Peserta didik untuk aktif belajar. Sedangkan pendidik bertugas membimbing Peserta didik dalam belajar. Untuk lebih jelasnya, peningkatan hasil belajar Peserta didik disajikan dalam grafik berikut:

Grafik Peningkatan Hasil Belajar Peserta didik

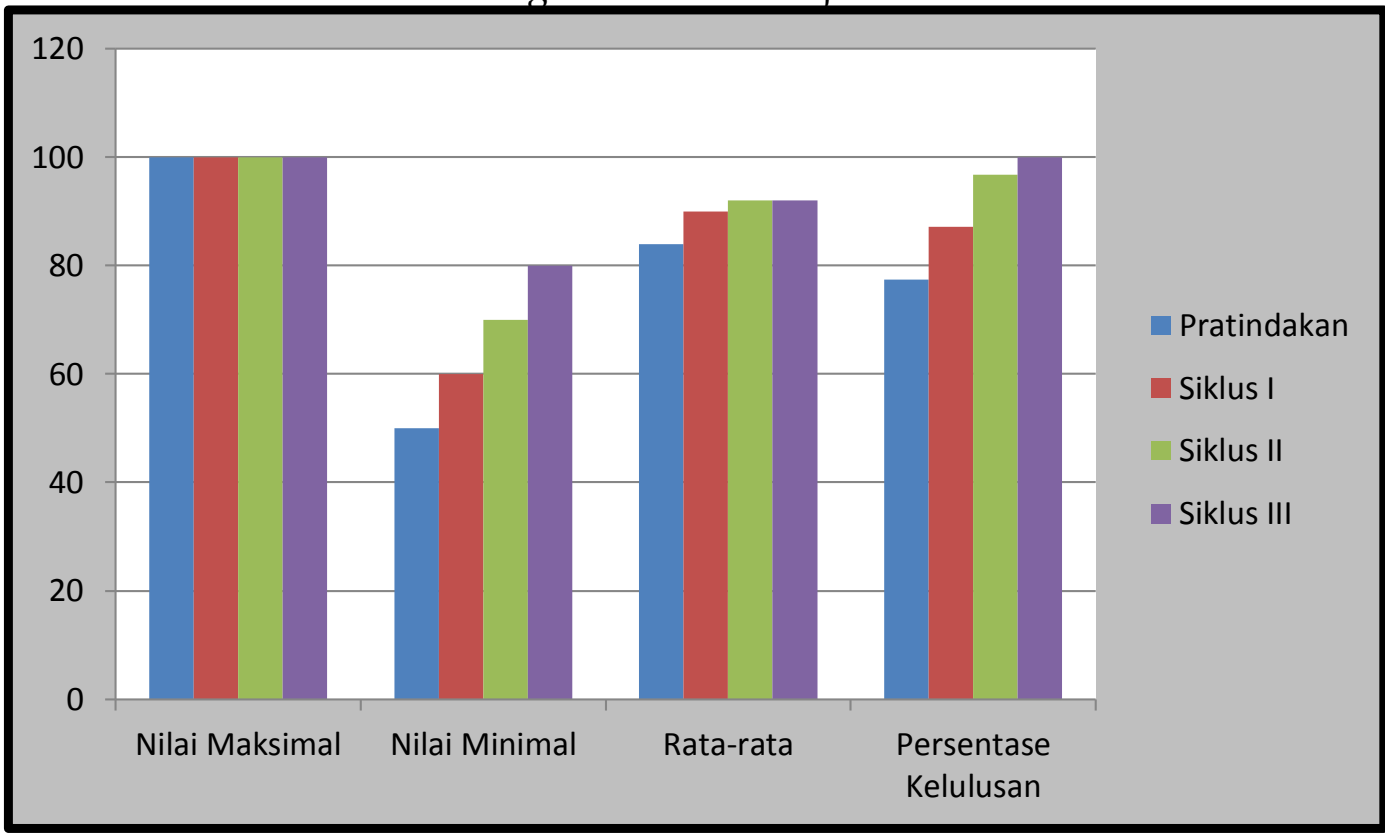


Pada grafik di atas peningkatan hasil belajar Peserta didik dalam materi iman kepada hari akhir. Pada Jumlah Maksimal memang tidak terjadi peningkatan. Namun dalam Jumlah Maksimal, nilai rata-rata, dan persentase kelulusan mengalami kenaikan yang cukup signifikan. Berdasarkan hasil tindakan pembelajaran dengan pendekatan CTL berbasis multimedia pembelajaran interaktif dapat meningkatkan keaktifan dan hasil belajar pada materi iman kepada hari.

\section{PENUTUP}

Implementasi Contextual Teaching and Learning (CTL) berbasis multimedia interaktif dapat meningkatkan keaktifan Peserta didik kelas IX A SMP Negeri 2 Tengaran Kab. Semarang. Sejak awal penggunaan multimedia Peserta didik telah aktif untuk mempelajari materi pembelajaran yang terdapat pada media tersebut. Hal itu tampak pada kesenjangan antara kegiatan pembelajaran yang mengharuskan Peserta didik untuk belajar dengan media dan tidak dengan media. Semua Peserta didik menggunakan media tersebut dengan baik, sebesar 100\% sejak siklus I hingga siklus III. Persentase keaktifan Peserta didik cukup rendah dalam kegiatan yang tidak menuntut penggunaan media, seperti keaktifan dalam tanya jawab yang hanya $12.9 \%$ pada siklus I dan meningkat menjadi $38.7 \%$ pada siklus II, dan 87.1 pada siklus III. Begitu juga keaktifan Peserta didik dalam belajar kelompok. Semula hanya $32.3 \%$ pada siklus I, meningkat menjadi $83.9 \%$ pada siklus II dan $96.8 \%$ pada siklus III. Sedangkan keaktifan paling rendah terdapat pada keikutsertaan Peserta didik dalam presentasi hasil belajar kelompok. Pada siklus I hanya 9,7\%, 42.9\% pada siklus II, dan $74.2 \%$ pada siklus III. Sedangkan dalam mencatat materi pembelajaran, keaktifan Peserta didik cukup baik, walaupun belum 100 \% pada siklus I dan II. Semua Peserta didik baru mencatat materi pembelajaran pada siklus III.

Implementasi Contextual Teaching and Learning (CTL) berbasis multimedia interaktif dapat meningkatkan hasil belajar Peserta didik IX SMP Negeri 2 Tengaran Kab. Semarang. Pada kegiatan pratindakan, nilai maksimal sebesar 100. Begitu juga pada siklus I, II, dan III. Pencapaian nilai minimal pada kegiatan pratindakan sebesar 50 dan terus meningkat 10 point menjadi 60 pada siklus I, 70 pada siklus II, dan 80 pada siklus III. Nilai rata-rata juga mengalami kenaikan yang cukup signifikan. Pada pembelajaran pratindakan, nilai rata-rata hanya sebesar 84. Pada siklus kedua meningkat menjadi 90, pada siklus II dan siklus III meningkat menjadi 92. Begitu juga dengan persentase ketuntasan meningkat dari 77.42 pada pembelajaran pratindakan, berubah menjadi 87.10 pada siklus II, 96.77 pada siklus II, dan 100 persen pada siklus III. 


\section{DAFTAR PUSTAKA}

Abdurrahman, Mulyono. Pendidikan bagi Anak Berkesulitan Belajar. Jakarta: Pusat Perbukuan Departemen Pendidikan dan Kebudayaan dengan Penerbit PT. Rineka Cipta, 2003.

Dimyati, dan Mudjiono. Belajar dan Pembelajaran. Jakarta: Pusat Pembukuan Departemen Pendidikan dan Kebudayaan dan Rineka Cipta, 2006.

Dryden, Gordon dan Jeanette Vos. The Learning Revolution: to Change The Way The World Learns. Canada: The Learning Web, 1999.

Hadi, Sutrisno. Metodologi Research. Jakarta: UGM Press, 1980.

Khasanah, Skripsi: Peningkatan Kreativitas Siswa dalam Pembelajaran Matematika Melalui Media Interaktif Berbasis Komik (PTK di Kelas IV SD Negeri 1 Kuripan Purwodadi, (Universitas Muhammadiyah Surakarta: 2009, ) didownload hari 5 Oktober 2015

Mustofa, Agus, Ternyata Akhirat Tidak Kekal, Cet. X. Surabaya: Padma Press, 2006.

Narbuko, Cholid dan Abu Ahmadi. Metodologi Penelitian. Cet. VIII. Jakarta: Bumi Aksara, 2007.

Rohmat, H. Media Pembelajaran: Suatu Pengantar. Yogyakarta: Logung Pustaka, 2010.

Sadiman, Arif, dkk. Media Pendidikan: Pengertian, Pengembangan dan Pemanfaatan. Jakarta: PT Raja Grafindo Persadar, 2003.

Sanjaya, Wina, Strategi Pembelajaran: Berorientasi Standar Proses Pendidikan. Jakarta: Kencana, 2008.

Sanjaya, Wina. Pembelajaran dalam Implementasi Kurikulum Berbasis Kompetensi. Bandung: Fajar Interpratama Offset, 2005.

Saputro, Eko Bambang, Tesis: Kontribusi Media Pembelajaran Interaktif Program Macromedia Flash Profesional 8 untuk Membantu Meningkatkan Pemahaman Konsep Pembiasan Cahaya pada Siswa Kelas X SMA Negeri 1 Mijen Demak Tahun 2008/2009 (Universitas Negeri Semarang, 2009, ) didownload hari Senin, 5 Oktober 2015.

Subagyo, Joko. Metode Penelitian, dalam Teori dan Praktik. Jakarta: Rineka Cipta, 1991.

Sudjana, Nana. Penilaian Hasil Proses Belajar Mengajar. Bandung: PT. Remaja Rosdakarya, 2006.

dan Ahmad Rivai. Media Pembelajaran. Bandung: sinar Baru Algesindo, 2001.

Sugiyono. Memahami Penelitian Kualitatif. Cet. III. Bandung: Alfabeta, 2007.

Sukmadinata, Nana Syaodih. Metode Penelitian Pendidikan. Bandung: PT. Remaja Rosdakarya, 2007.

Sulaiman, Amir Hamzah. Media Audio Visual. Jakarta: Gramedia, 1985. 
FITRAH Vol.02 No. 1 Januari-Juni 2016

Sri Sugiyartik, "Melalui Media Pembelajaran CD Interaktif untuk Meningkatkan Prestasi Belajar IPA tentang Sistem Peredaran Darah Menusia Bagi Siswa Kelas V SD Gembyungan 2 Kecamatan Randublatung Kabupaten Blora Pada Semester Gasal Tahun 2008/2009" () didownload hari Selasa, 6 Oktober 2015.

Wiriaatmadja, Rochiati. Metode Penelitian Tindakan Kelas: untuk Meningkatkan Kinerja Guru dan Dosen. Cet. VIII, Bandung: Rosdakarya, 2009. 